\title{
Strategic use of debt in Flemish municipalities
}

\author{
Stijn Goeminne \& Carine Smolders ${ }^{l}$
}

Faculty of Business Administration and Public Administration

University College Ghent

Voskenslaan 270, B-9000 Ghent, Belgium

e-mail: stijn.goeminne@hogent.be, carine.smolders@hogent.be

\section{Key-words}

Strategic debt models, Flemish municipalities, Probability of electoral defeat, Vote function

\begin{abstract}
This paper discusses the literature on strategic use of debt models and empirically tests the seminal models of Persson \& Svensson (1989) and Alesina \& Tabellini (1990) on a dataset of Flemish municipalities. The literature on strategic use of debt originates from the question whether incumbent policy makers run higher budget deficits if they expect an electoral defeat. We introduce a vote function to estimate the probability of electoral defeat and present evidence of strategic debt in line with Persson \& Svensson (1989). Moreover, we show that coalition governments in particular are more likely to increase debt strategically.
\end{abstract}

\section{Introduction}

Though tax-smoothing theory (Barro, 1979) suggests that deficits and surpluses are used to minimize the distorting effects of taxation, political economy models not only relate deficits and debt to the business cycle; they also point to the role of the timing of elections when

1 Corresponding author: Stijn Goeminne, e-mail: stijn.goeminne@hogent.be, Tel: +329248 88 34, Fax: +32 9242 42 09. The authors are grateful to Benny Geys, Bruno Heyndels and Marc Jegers for helpful comments on a previous version of this paper and to Jan Vermeir \& Bruno Heyndels and Benny Geys for sharing their dataset. We also gratefully acknowledge the financial support of the Faculty of Business Administration and Public Administration, University College Ghent. 
framing fiscal policy. ${ }^{2}$ This literature suggests that governments change fiscal policy to attract more votes and to increase their chances of getting re-elected. ${ }^{3}$ But it is not only governments who believe they have a good chance of staying in office that may change fiscal policy. An interesting finding is that governments expecting to be replaced might adapt fiscal policy too. The time-inconsistency theory of politics (see Kydland \& Prescott, 1977; Fischer, 1980) predicts that judgements about the likelihood of a regime change drive policy changes. A government expecting a regime change may opt to follow a second-best policy when this allows to control the fiscal setting of the future government. The creation of debt by the previous government puts a constraint on the new government that will have no choice but to accept it, possibly having to sacrifice parts of its own expenditure programme. This situation is described in the literature on strategic deficit and debt behaviour.

In this paper we investigate empirically whether strategic debt behaviour is present in Flemish municipalities. Crucial in empirical tests on strategic debt behaviour is to find a good proxy for the government's expectation of a regime change. For this purpose most previous empirical analyses on strategic debt models introduce historical political stability information. The approach taken here, on the other hand, is that a variable which measures the probability of electoral defeat should be based on the electorate's determinants to evaluate the government's policy. Therefore, we introduce the literature on vote functions to estimate the probability of electoral defeat.

The remainder of the paper is organised as follows. Section 2 is an overview of the relevant literature. Section 3 formulates some observations on the present state of the research in this field. Section 4 presents models to estimate the probability of electoral defeat and to empirically test the presence of strategic use of debt. Some extensions are presented in section 4.4. Finally, we conclude in section 5 .

\section{The literature}

The literature on strategic deficit and debt behaviour originates from the question whether incumbent policy makers run higher budget deficits than they would otherwise do if they were confident of re-election?

The strategic use of debt literature arises from the paper of Persson \& Svensson (1989) (henceforth PS model). The PS model argues that voters have heterogeneous preferences

2 Still there are several other political economic models that explain budget deficits, such as the ideological orientation and political fragmentation of the government, the form of the budgetary institutions, the degree of government stability, and so on. See Franzese (2001) for an excellent overview.

3 For example Alesina et. al. (1992) find evidence of systematic differences in fiscal and monetary policy in preelection years. 
concerning the size of the government. Some of the voters want the government to provide a significant level of public goods, while others are in favour of less government interference. The PS model assumes that incumbents adapt to the voters' preferences and act accordingly. This model predicts rightist governments awaiting a regime switch to run budget deficits up to a much higher level than when they feel secure about their political future. The idea is to reduce the public spending of the following (leftist) government by creating more debt. Higher levels of debt bring along higher interest charges and thus reduce the scope for policymaking of the next government. The opposite reaction is expected when a leftist government anticipates a regime change. Leftist governments traditionally favour higher public expenditures. The PS model predicts that leftist governments will run a budget surplus if they know they will be succeeded by a rightist government. This budget surplus enlarges the budget of the succeeding rightist government and induces it to spend more than it otherwise would have.

The theoretical work of Persson \& Svensson (1989) was followed by the contribution of Alesina \& Tabellini (1990) (henceforth AT model), also theoretical in nature. This paper also emphasizes strategic considerations in the formation of debt policy, but from a different viewpoint. While the PS model focuses on the level of spending, the AT model assumes that governments differ with respect to their preferences concerning the composition of government spending. Again this is a reflection of the voters' preferences. When the government expects to be replaced, it runs a budget deficit which will bring the composition of future public spending closer to its preferences. In fact, the deficit allows the current government to spend more on public goods that it prefers by reducing future spending on the public goods it gets little utility from. ${ }^{4}$

The AT model expects a deficit bias irrespective of the government's political ideology; that is, regardless of the government's political preferences, the existence of a strong likelihood of being voted out of office will generate an incentive to issue debt. The AT model thus yields a symmetric prediction on the role of the probability of electoral defeat. The PS model's prediction, on the other hand, is non-symmetric. This model predicts that only right-wing governments issue debt. So whereas in the AT model the probability to be voted out of office raises debts per se, this is only the case for right-wing governments in the PS model. The AT and PS model also differ with respect to the assumptions made concerning the utility functions of the parties. They both assume that the political polarization and the likelihood of a regime

4 Consider, for example, a government which prefers spending on education to road construction and assume that it expects to be replaced by a government with the opposite preferences. The current government could expect that spending on education will be cut by the next government. Therefore it can opt to run up a deficit and spend the extra resources on education as an advance on the spending cut in education that will follow with the take-over of the next government. Today's government thus ties the hands of future governments by allocating future tax revenues to service debt. The marginal cost of repaying the additional debt falls thus on the preferences of the new government, about which the departing government cares little. 
switch are major determinants of the pre-electoral debt policy. Fiscal policy will thus be more volatile when governments expect to be replaced than when they don't.

Various authors have extended, criticized or empirically tested the PS and AT models. ${ }^{5}$ Lockwood et al. (1996) build on the PS model. They assume that two parties alternate in power and have different preferences over the level of public good provision and then innovate in assuming that incumbents do not care about -or care sufficiently little about-policy outcomes when not in power. This means that parties in power are expected to be myopic near the end of their term of office. Incumbents have the incentive to finance their expenditures by issuing debt, knowing that they will not have to face the consequences of debt financing for a while -the so-called "quasi-finite horizon effect". According to Lockwood et al. (1996), this implies that pre-electoral debt expansion is dominating the strategic effects of the PS model, so that in their models trategic effects appear of only secondary importance. Incumbents only have an incentive to use debt strategically to affect their successor's tax and spending decisions insofar as it influences the level of debt that the (current) incumbent party will inherit when it is next returned to power. So, predominantly, the "quasi-finite horizon effect" rules.

The Martimort (2001) model contradicts the expectations of the PS model. The major contribution of the Martimort (2001) model is that it stresses the strategic role of budget deficits when parties differ only with respect to their redistributive concerns. ${ }^{6}$ According to Martimort (2001), political regime switching introduces fluctuations in the distribution of utility in the economy. These fluctuations justify strategic budget distortions by governments currently in office and willing to favour their redistributive concerns against the policies of a future government. Contrary to the PS model, Martimort (2001: 573) expects "leftist governments to be more inclined to redistribute income. By running a deficit today, the leftist government ensures that society gets poorer tomorrow. A future rightist government will have to redistribute more. The implemented tax policy will thus be close to what a leftist government would have chosen itself. On the contrary, by running a surplus today, a rightist government relaxes the burden of taxation imposed by tomorrow's leftist government on high income agents. This leftist government will be less eager to redistribute and will adopt the rightist party's behaviour."

5 Aghion \& Bolton (1990), Milesi-Ferretti (1995) and Milesi-Ferretti \& Spolaore (1994) also present models that explain the strategic use of debt, but from another point of view. These authors assume that budget deficits are used strategically to influence election outcome. They focus on the impact of debt decisions on the probability of getting re-elected, while in the seminal strategic debt models of AT and PS -the subject of our analysis- the causality is inverse. Therefore we do not go more deeply into these papers.

6 While each type of government maximizes a social welfare function, a rightist government prefers more allocative efficiency and less redistribution than a leftist government. 
For empirical research on strategic debt models, we refer to the findings of Pettersson-Lidbom (2001), Lockwood et al. (1996), Carmignani (2003), Crain \& Tollison (2003), Grilli et al. (1991), Lambertini (2003), Franzese (2001) and Ashworth et al. (2005).

Pettersson-Lidbom (2001) and Lockwood et al. (1996) present evidence consistent with the PS model. Pettersson-Lidbom (2001) examines the accumulation of debt by Swedish local governments and finds significantly positive effects of the probability of electoral defeat on the accumulation of debt. Moreover he finds strong differences between right- and left-wing governments. As expected by the PS model, right-wing governments accumulate more debt $(+15 \%)$ when facing a higher probability of defeat, whereas the opposite occurs for left-wing governments (-11\%). Lockwood et al. (1996) not only build on the PS model theoretically but also test their hypotheses empirically. Using annual data for the United Kingdom on government debt (and taxes and expenditures) for the period 1956 to 1996, their empirical findings are largely consistent with the theoretical expectations (as described earlier).

Carmignani (2003) and Crain \& Tollison (1993) build on the AT model and find empirical support for it. For a sample of western European democracies, Carmignani (2003) shows that government instability - when it involves a replacement of decision-makers- increases the size of deficits. Crain \& Tollison (1993) employ data from U.S. states covering the period 1968 to 1989 and report that as the likelihood of a government change increases, the volatility of fiscal measures -and specifically taxes and the surplus/ deficit levels- increases.

Other empirical studies by Grilli et al. (1991), Lambertini (2003), Franzese (2001) and Ashworth et al. (2005) find no significant evidence for the strategic use of debt or deficits. Grilli et al. (1991) investigate the reasons for the existence of differences in the debt-to-GNPratio in 18 OECD countries over the period 1960-1989, but find no evidence that supports the PS or AT models. Lambertini (2003) uses U.S. (1960-1995) and pooled data for 16 OECD countries (1960-1992) to test both the PS model and the AT model. For the U.S. dataset opinion polls are used to measure the probability of being voted out of office, while for OECD countries a probit equation on the probability of government change is estimated. For the AT model, Lambertini (2003) tests whether government outlays on defence are higher under more conservative governments and whether government expenditures on social security and welfare are higher under more liberal governments. For the PS model, Lambertini (2003) investigates whether cyclically adjusted government budget surpluses are lower under conservative than liberal governments. Results show that there is no evidence that confirms the expected effects, irrespective of the model adopted (AT or PS). For none of the datasets as measured by Lambertini (2003) does the probability of being voted out of office have a significant effect on the government budget surplus. 
Franzese (2001) examines the political determinants of debt and deficits for 21 OECDcountries and, like Lambertini (2003), rejects the predictions of strategic use of debt models. Franzese's (2001) bivariate analysis shows that his "risk replacement variable" does not correlate with debts or deficits. As Franzese (2001) points out himself, a bivariate analysis is actually inapt for exploring conditional hypotheses like strategic use of debt theories. More importance, he argues, should be attached to his multivariate analyses. His multivariate model, however, provides no support for strategic debt policy. The risk replacement variable is marginally significant and suggests that the probability of being voted out of office provokes governments to engage in debt policy manipulation, but contrary to the PS model, leftist governments increase and rightist governments decrease deficits when the replacement risk increases.

Finally, Ashworth et al. (2005) examine the impact of government fragmentation on local government indebtness in Flemish municipalities for the period 1977-2000. Their analysis shows no significant impact of the number of excess seats of the ruling parties on local debt. Therefore they conclude that the lack of a significant impact "indicates a lack of evidence for strategic debt usage in Flanders".

To summarize, the empirical evidence in the literature shows no consensus on whether or not the incumbent's probability of being voted out of office, or its political colour, explains budget deficits.

\section{Discussion}

Although different models provide theoretical explanations for budget deficit or debt changes, the empirical evidence is relatively weak. This does not necessarily mean that the strategic models can be refuted. But some observations can be made.

First, the empirical disagreement indicates that fiscal decisions are the outcome of a more complicated political process. Variables other than the probability of being voted out of office also seem to matter for fiscal policy. Lambertini (2003) suggests that macro-economic and other exogenous events not accounted for in the PS or AT models also explain budget deficits or surpluses. To reduce the impact of these exogenous events, it might be advisable to look for evidence of the strategic use of debt behaviour on single-country data, so that the impact of these types of events is constant over all observations. Consequently it is not coincidental that Pettersson-Lidbom (2001) finds evidence of the existence of the strategic use of debts when analysing Swedish municipalities. 
Second, we could question whether evidence of the strategic use of debt models can be found outside two-party systems or similar situations. The AT model is developed in a two-party environment. The PS model explains the behaviour of "a" rightist government expecting to be replaced by "a" leftist government or vice versa, but gives no consideration to the precise composition of each government. What if more than two parties are running for government? The empirical tests that support the strategic use of debt models have all been performed on governments operating within a two-party system ${ }^{7}$. We suggest that the strategic use of fiscal policy becomes less attractive the larger the coalition becomes. This is because increasing debt might reduce the future policy options of one or more of the coalition partners who might return to office as members of a new coalition. This is not unlikely in coalition governments since the probability that at least one of the members stays in office increases the higher the number of coalition partners. Grilli et al. (1991) also point out that changes in coalition governments are rarely due to a total breakdown of the underlying coalition.

Third, the theoretical PS model assumes that incumbents know that they will be replaced. What about the situation when electoral uncertainty leads to uncertainty about the nature of succeeding governments? Although Persson \& Svensson (1989, 342) conjecture that uncertainty about whether the current government will remain in power or not would not fundamentally change their findings, Alesina \& Tabellini (1990) introduce uncertainty in their theoretical model. In fact, empirical models also differ from the PS model and introduce a variable that measures the probability of electoral defeat to take into account uncertainty. Reviewing the literature, we find as many approaches to calculating that probability as there are empirical studies on the strategic use of debt. In addition to differences in model specification such as time period, sample or differences in the definition of what is seen as deficit or debtwe suggest that the definition of the crucial variable concerning re-election prospects may explain the inconsistency in the empirical findings. We do not dispute that what moves governments to act strategically (or not) before elections is their assessment of upcoming electoral outcomes. We only address disagreement in the construction or measurement of that crucial variable.

\section{Empirical analysis}

The setting of our empirical analysis follows from the considerations above. We empirically test the existence of strategic debt models on single-country data. Our dataset consists of Flemish municipalities in which multiple parties with various ideological characteristics compete for

\footnotetext{
Although Swedish local governments operate in a multi-party system, Pettersson-Lidbom (2001, 575, footnote 10) reduces his dataset to a two-party environment, only taking into account strict left- or right-wing governments. Undefined governments, that is when neither left-wing nor right-wing parties constitute a majority, are removed from the dataset.
} 
office in a system of proportional representation. Therefore our analysis will take into account ideological differences as well as possible fragmentation effects. Finally, we take into account uncertainty about future government participation. Our crucial variable to proxy the probability of electoral defeat is not constructed ad hoc, but is derived from the literature on vote functions.

First we discuss some characteristics of Flemish local governments. Second we introduce a vote function to proxy the probability of electoral defeat. Third we test the presence of strategic use of debt in Flemish municipalities. The construct of the analysis permits a distinction between the PS- and AT-variants of strategic use of debt models. Finally some extensions to the analyses are presented.

\subsection{Flemish municipalities}

Flemish local governments have a parliamentary system consisting of the local council (the legislative body) and the College of Mayor and Alderman (the executive body). Seats in the council are allocated using a system of proportional representation. The composition of the College is determined by the party (or parties) holding a majority position in the council. Elections are hold every 6 years and incumbents can be indefinitely re-elected (i.e. there are no binding term limits).

Flemish municipalities enjoy a far-reaching autonomy in their fiscal policies. Taxation and grants from higher levels of government (which are for the most part unconditional) are important sources of revenue. Expenditures may also be financed through debt-financing. Flemish municipalities can arrange public loans, still they borrow almost exclusively from private banks.

The fiscal year runs parallel to the civil year in Belgium (from 1 January to 31 December). Prior to the fiscal year, a balanced budget needs to be agreed upon. The presentation of the budget is a responsibility of the College. The budget is discussed by the College of Mayor and Alderman and is brought before the local council for ratification. Only when the budget is endorsed before 31 December, it can be executed.

\subsection{Expectation of electoral defeat}

The strategic debt models assume that governments that expect to be replaced will change debt before elections. Crucial in these models is the introduction of a measure for the probability of electoral defeat. Pettersson-Lidbom (2001), Carmignani (2003) and Lambertini (2003) create each a -different- auxiliary equation that links the unobserved variable, that is, the expectation of electoral defeat, to a set of observable variables that might be expected to affect the 
probability of electoral defeat. The Pettersson-Lidbom (2001) set of explanatory variables is restricted to historical voting patterns and the frequency of previous government changes. Franzese (2001), Grilli et al. (1991), Ashworth et al. (2005) and Crain \& Tollison (1993) also use historical stability variables. Franzese (2001) launches a "replacement risk variable", which is simply the inverse of the actual duration in years of the incumbent's mandate, i.e., the hazard rate of losing office in a year. Grilli et al. (1991) use the frequency of government changes in the past, while Crain \& Tollison (1993) measure the probability of no regime change from historical seats shares. Ashworth et al. (2005) use the number of seats in excess of a simple majority (since previous elections). Carmignani (2003) estimates the probability of government termination by a probit analysis with different variables. Besides the stability of the government in the previous year, political fragmentation, political polarization and GDP growth in the current and previous year are introduced into the equation. Lambertini (2003) introduced two constructs to estimate a government's prospects. She first estimates an index of political affiliation of the government, calculated on election dates, change-of-government dates, the direction of the change in government and the ideological position of the government. A change in the value of the index is thus a change in the government in the Lambertini (2003) model. Secondly, in her analysis on U.S. data, she introduces opinion polls as proxy for the probability of electoral defeat. ${ }^{8}$

Different authors used different methods to estimate the probability of electoral defeat. The question of what a good proxy might be remains open. We are conscious that the real expected probability of re-election or electoral defeat is hard to measure. The literature so far is focused on historical political stability determinants only. As well as these, other determinants, such as economic, tax and political variables, may explain whether incumbents get re-elected or not. Ultimately, when judging the probability of electoral defeat, incumbents need to assess voters' likely behaviour in the voting booth. It thus becomes important for incumbents to evaluate the relevant determinants that voters have in mind when voting for or against the current government. The determinants of voting behaviour have been studied intensively in the literature on vote functions (see e.g. Paldam \& Schneider, 1980; Nannestad \& Paldam, 1994, Lewis-Beck \& Paldam, 2000; Revelli, 2002; Vermeir \& Heyndels, 2006; Geys \& Vermeir, 2008). In general these functions explain the vote (or the change in the vote) for the government at elections by (the change in) political, economic and tax variables (Nannestad \& Paldam, 1994).

8 We do not dispute the accuracy of opinion polls, but we are not convinced that this is the best proxy for the government's expectation of electoral defeat in a multiparty system. Typically, and as in Lambertini (2003), opinion polls do not poll for the continuation of the government, which is the crucial variable in the literature on the strategic use of deficits or debt, but for the intention of the electorate to vote for a specific party or a specific candidate. Therefore, although opinion polls can be used to estimate the probability of electoral defeat in a twoparty system, this is not obvious in a multi-party system as in our dataset. 
Though part of the political variables are historical stability variables, vote functions are not restricted to these.

The novelty of this paper is that we introduce a vote function to measure the expectation of the probability of electoral defeat. Mughan (1987: 198) makes clear that the primary purpose of vote functions should be forecasting -"predicting the outcome of an event before it occurs"instead of explaining. Norpoth \& Gschwend (2003) also show that a model based on the insights from electoral research could be a good instrument to predict the level of votes cast for incumbents. In this paper we will use the insights of vote function models to estimate the probability of electoral defeat of the incumbents. If they expect not to remain in power, the incumbents could decide to act strategically.

In our analysis we estimate the prospects of electoral defeat from a variant of Vermeir \& Heyndels' (2006) vote function for Flemish municipalities. To test whether yardstick voting is present in Flemish municipalities, Vermeir \& Heyndels (2006) empirically analyse the votes at municipal elections. They find that incumbents are punished for higher tax rates. Moreover, the electoral punishment depends on the tax rates in neighbouring municipalities, so empirical evidence of yardstick competition is provided. Next to the tax variables -the focus of the Vermeir \& Heyndels (2006) research- their analysis also contains political and economic variables. As such their model is a good starting point given the purpose of this paper.

To take into account the incumbents' judgement of their electoral prospects in the explanation of debt policy in election years, we adjust Vermeir \& Heyndels' (2006) vote function. These adjustments are necessary as Flemish local governments have to endorse the (Balanced) Budget before December 31 of the year before. If incumbents would like to act strategically in the election year, increases in the level of debt thus should be agreed on in the year before elections. The decision whether or not to increase local debt strategically in election year $t$ thus has to be made in year $\mathrm{t}-1$. Incumbents thus have to judge their electoral prospects one year before elections. Therefore we first re-estimate the Vermeir \& Heyndels (2006) vote function using the one-year lagged values of (most of) their explanatory variables. Second we calculate the forecasted values of the vote percentage. These forecasted values should represent the incumbents' expectation at t- 1 of the percentage of votes they may expect to get in election year t. ${ }^{9}$

First, we adapt Vermeir \& Heyndels' (2006) vote function for the purpose of our research. Compared to them, in equation (I.) all explanatory variables are one year lagged to take into account the fact that incumbents have to estimate their probability of electoral defeat in the

9 We would like to emphasize that there are no elections in year $\mathrm{t}-1$. We only assess at the timing of t -1 the votes the government party (parties) may expect at the upcoming elections by introducing explanatory variables of the year t1. 
year before elections -except for the vote percentage of the same government party (parties) in the previous elections $\left(\mathrm{V}_{\mathrm{it}-6}\right)$. Equation (I.) explains the percentage of votes the incumbent party (or parties ${ }^{10}$ ) receives at the elections in year $t$ given the economic, political and tax variables of pre-election year $\mathrm{t}-1$ :

$$
\text { (I.) } \begin{aligned}
\mathrm{V}_{\mathrm{it}}= & \alpha_{1}+\alpha_{2} \mathrm{~V}_{\mathrm{it}-6}+\alpha_{3} \mathrm{TAX}_{\mathrm{it}-1}+\alpha_{4} \mathrm{NTAX}_{\mathrm{it}-1}+\alpha_{5} \mathrm{EXP}_{\mathrm{it}-1}+\alpha_{6} \mathrm{NEXP}_{\mathrm{it}-1}+\alpha_{7} \mathrm{NTI}_{\mathrm{it}-1} \\
& +\alpha_{8} \mathrm{UNEMPL}_{\mathrm{it}-1}+\alpha_{9} \mathrm{NPAR}_{\mathrm{it}-1}+\text { year dummies }+ \text { party dummies }+\mathrm{u}_{\mathrm{it}-1}
\end{aligned}
$$

where: $\mathrm{i}=1, \ldots, \mathrm{N} ; \mathrm{t}=$ election years

$\mathrm{V}_{\text {it }}$ represents the vote percentage of the government party (parties) of municipality $i$ in election year t. The first explanatory variable is the vote percentage of the same government party (parties) in the previous elections $\left(\mathrm{V}_{\mathrm{it}-6}\right)$. The coefficient of $\mathrm{V}_{\mathrm{it}-6}$ is expected to have a positive impact on the number of votes. ${ }^{11} \mathrm{TAX}_{\mathrm{it}-1}$ is a vector of tax instruments and includes the local income tax rate $\left(\mathrm{LITR}_{\mathrm{it}-1}\right)$ and the local property tax rate $\left(\mathrm{LPTR}_{\mathrm{it}-1}\right)$. We expect the tax rates to have a negative impact on the vote percentage. Per capita public expenditure $\left(\mathrm{EXP}_{\mathrm{it}-1}\right)$ is included to measure for the quantity (and/ or quality) of public output. A positive impact on the votes is expected from this. We refer to the theory of yardstick voting -which suggests that voters compare their own municipality to their neighbouring municipalities when deciding on their vote (Besley \& Case, 1995 and Revelli, 2002) - to include also the average local tax rates

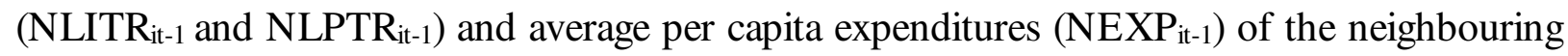
municipalities. ${ }^{12}$ Average local tax rates of neighbouring municipalities are expected to positively affect the votes, while negative values are anticipated for the average per capita expenditures of the neighbouring municipalities. As the literature on economic voting13 suggests that governments are held accountable for economic developments, net taxable

10 The vote share corresponds with the sum of the share of the coalition partners in the case of coalition governments.

11 Two remarks concerning this variable. First, this variable is not strictly a lagged dependent variable. This could be a lagged dependent variable, but only when the previous government stayed in office. Second, the definition of this variable implies that the dataset does not contain data of all Flemish municipalities. Sometimes it is impossible to calculate previous election results of the government. Parties may split up, merge with another party or change their names. Also parties can disappear and not compete in next elections or a member of the government can change parties. The dataset -that corresponds with that of Vermeir \& Heyndels (2006)- only contains observations of which previous election results can be indisputably calculated. We thus are confronted with an unbalanced panel as we do not have observations for every election in every municipality. Finally our dataset contains 688 observations of 294 (out of 308) municipalities.

12 All "neighbouring" variables are estimated as the unweighted average of the values of the Flemish neighbouring municipalities. For Flemish municipalities across the language boundary, only Flemish neighbours are taken into account. Therefore Voeren is removed from the dataset as it has no Flemish neighbours.

13 The literature on economic voting presumes that voters observe the government's management of the economy. In short, if the economy does well, voters conclude that the government is competent. If the economy does poorly, they conclude that the government is bad. In the former case, voters re-elect the government, in the latter case they vote for the opposition. See Lewis-Beck \& Paldam (2000) for an overview. 
income $\left(\mathrm{NTI}_{\mathrm{it}-1}\right)$ and the unemployment rate (UNEMPL $\left.\mathrm{Lt}_{\mathrm{it}}\right)$ are introduced. ${ }^{14}$ Income is expected to have a positive effect on votes, while the opposite is true for unemployment. Political characteristics enter vote function (I.) through the number of government parties $\left(\mathrm{NPAR}_{\mathrm{it}-1}\right)$ which measure for clarity of accountability. More coalition partners are expected to reduce transparency. Fragmented governments are thus held less accountable for positive and negative developments (Powell \& Whitten, 1993). As governments are more punished for negative developments than they are rewarded for positive developments, Nicholson \& Segura (2002) show that fragmented governments generally suffer smaller electoral losses. A positive effect of the number of government parties on the vote is thus expected. The possibility of vote swings among government parties is another possible explanation for a positive coefficient as it is less clear which party voters might hold responsible for policy. Year dummies are introduced to capture possible year effects. ${ }^{15}$ Finally, party dummies are introduced, as Heath et al. (1999), Jérôme \& Lewis-Beck (1999) and Revelli (2002) show that local election results reflect national party popularity rather than the appreciation of local developments and policies. The impact of national or regional politics on local elections is captured by the inclusion of party dummies for the five national parties that participated in municipal governments. ${ }^{16}$

Estimating function (I.) is technically analogous to Vermeir \& Heyndels (2006). While Vermeir $\&$ Heyndels (2006) estimate the votes in the election year $t$, we estimate at the time of $t-1$ the vote percentage which the government party (parties) may expect at elections in year $\mathrm{t}$ by implementing one-year lagged explanatory variables. We estimate vote function (I.) using an IV-approach in which internal and neighbouring tax variables are instrumented. ${ }^{17}$ Frey \& Schneider (1978) and Schneider \& Pommerehne (1980) show that tax variables in the UK and Australia respectively may not be assumed to be exogenous, as the level of popularity affects tax policy. We thus may expect that the error term is correlated with the tax rates. Neighbouring tax variables are instrumented because the presence of spatial correlation in the error is suggested by Revelli (2001) and Solé Ollé (2003) in their models on tax mimicking. We follow Vermeir \& Heyndels (2006) by instrumenting own tax rates and per capita expenditures by the percentage of young people and elderly, the average sale price of small and middle sized houses and the number of inhabitants. Tax rates and per capita expenditures of neighbouring

14 Remark that these economic variables are the result of macro-economic policy which is mainly a federal and regional responsibility. Despite their objective to interfere local governments may still have a (marginal) influence or may be held accountable by the electorate. Local governments can e.g. approve the layout of additional company grounds or decide to lower local company taxes to stimulate local economic activity.

15 Year effects are introduced to measure the electoral change common to all governments in a certain year. Vermeir \& Heyndels (2006, footnote 20 p. 2291) provide the example of the electoral rise of the extremist party Vlaams Blok (Vlaams Belang).

16 We introduced dummies for the liberal democratic VLD, for the social democratic SP.a, for the Christian democratic $C D \& V$, for the ecologist GROEN! and for the nationalist VU. The extreme-right Vlaams Blok (Vlaams Belang) participates in none of the local governments.

17 These "neighbouring tax variables" are the local income tax rate, the local property tax rate and per capita expenditures. 
municipalities are similarly instrumented. The Sargan tests on the validity of the instruments indicate that the instruments are valid. Table 1 presents the results of the estimation without -in columns (1) and (2)- and with party dummies -in columns (3) and (4). Descriptive statistics of all explanatory variables are shown in Table A1 on p. 28 in appendix.

Table 1 IV estimation of the vote share of the government parties in election year $\mathrm{t}$ at the timing of $\mathrm{t}-1$

\begin{tabular}{|c|c|c|c|c|}
\hline $\begin{array}{l}\text { Dependent variable : } \\
\text { Vote share of the government parties }\left(\mathrm{V}_{\mathrm{it}}\right)\end{array}$ & (1) & (2) & (3) & (4) \\
\hline Intercept & $\begin{array}{l}-4.858 \\
(-0.19)\end{array}$ & $\begin{array}{l}-6.065 \\
(-0.41)\end{array}$ & $\begin{array}{l}-1.463 \\
(-0.06)\end{array}$ & $\begin{array}{l}-0.556 \\
(-0.03)\end{array}$ \\
\hline Prior vote $\left(V_{\text {it- } 6}\right)$ & $\begin{array}{l}0.861 * * * \\
(2.65)\end{array}$ & $\begin{array}{l}1.022 * * * \\
(6.58)\end{array}$ & $\begin{array}{l}0.894 * * \\
(2.62)\end{array}$ & $\begin{array}{l}0.996 * * * \\
(5.59)\end{array}$ \\
\hline Local income tax rate $\left(\mathrm{LITR}_{\mathrm{it}-1}\right)$ & $\begin{array}{l}-6.600 * * \\
(-2.55)\end{array}$ & $\begin{array}{l}-5.349 * * * \\
(-3.47)\end{array}$ & $\begin{array}{l}-6.068 * * \\
(-2.16)\end{array}$ & $\begin{array}{l}-4.900 * * * \\
(-3.30)\end{array}$ \\
\hline Local property tax rate $\left(\mathrm{LPTR}_{\mathrm{it}-1}\right)$ & $\begin{array}{l}0.003 \\
(0.30)\end{array}$ & (1) & $\begin{array}{l}0.003 \\
(0.26)\end{array}$ & (1) \\
\hline Per capita expenditures $\left(\mathrm{EXP}_{\mathrm{it}-1}\right)$ & $\begin{array}{l}2.385 \\
(0.16)\end{array}$ & - & $\begin{array}{l}2.334 \\
(0.16)\end{array}$ & - \\
\hline Local income tax rate neighbours (NLITR $\left.\mathrm{N}_{\mathrm{it}-1}\right)$ & $\begin{array}{l}9.497 \\
(1.55)\end{array}$ & $\begin{array}{l}6.722 * * * \\
(2.77)\end{array}$ & $\begin{array}{l}7.967 \\
(1.26)\end{array}$ & $\begin{array}{l}5.859 * * \\
(2.46)\end{array}$ \\
\hline Local property tax rate neighbours $\left(\mathrm{NLPTR}_{\mathrm{it}-1}\right)$ & $\begin{array}{l}-0.006 \\
(-0.32)\end{array}$ & - & $\begin{array}{l}-0.004 \\
(-0.23)\end{array}$ & - \\
\hline Per capita expenditures neighbours $\left(\mathrm{NEXP}_{\mathrm{it}-1}\right)$ & $\begin{array}{l}-18.543 * * * \\
(-2.75)\end{array}$ & $\begin{array}{l}-14.125 * * * \\
(-5.07)\end{array}$ & $\begin{array}{l}-18.739 * * * \\
(-2.82)\end{array}$ & $\begin{array}{l}-13.40 * * * \\
(-5.19)\end{array}$ \\
\hline Net taxable income $\left(\mathrm{NTI}_{\mathrm{it}-1}\right)$ & $\begin{array}{l}-0.002 \\
(-0.31)\end{array}$ & - & $\begin{array}{l}-0.003 \\
(-0.34)\end{array}$ & $(0.1)$ \\
\hline Unemployment rate $\left(\mathrm{UNEMPL}_{\mathrm{it}-1}\right)$ & $\begin{array}{r}16.818 \\
(0.50)\end{array}$ & - & $\begin{array}{r}17.168 \\
(0.53)\end{array}$ & - \\
\hline Number of government parties $\left(\mathrm{NPAR}_{\mathrm{it}-1}\right)$ & $\begin{array}{l}1.878 \\
(1.58)\end{array}$ & $\begin{array}{l}1.473 * * \\
(2.21)\end{array}$ & $\begin{array}{l}1.241 \\
(0.48)\end{array}$ & - \\
\hline 1994 year effect $\left(Y_{94}\right)$ & $\begin{array}{l}-0.099 \\
(-0.06)\end{array}$ & - & $\begin{array}{l}-0.008 \\
(-0.01)\end{array}$ & - \\
\hline 2000 year effect $\left(\mathrm{Y}_{00}\right)$ & $\begin{array}{l}1.844 \\
(0.63)\end{array}$ & - & $\begin{array}{r}1.880 \\
(0.69)\end{array}$ & - \\
\hline Party effects & No & No & Yes & Yes \\
\hline Wald test party effects : F (p-value) & - & - & $\begin{array}{r}0.821 \\
(\mathrm{p}=0.54)\end{array}$ & $\begin{array}{l}10.971^{18} \\
(\mathrm{p} \delta .01)\end{array}$ \\
\hline $\mathrm{R}^{2}$ & 0.23 & 0.30 & 0.28 & 0.34 \\
\hline Adjusted $\mathrm{R}^{2}$ & 0.21 & 0.29 & 0.26 & 0.33 \\
\hline Sargan test of overidentifying restrictions (p-value) & $\begin{array}{r}2.08 \mathrm{E}-17 \\
(\mathrm{p} \times 0.99)\end{array}$ & $\begin{array}{r}0.963 \\
(p=0.92)\end{array}$ & $\begin{array}{r}4.35 \mathrm{E}-17 \\
(\mathrm{p} \times 0.99)\end{array}$ & $\begin{array}{r}0.844 \\
(p=0.93)\end{array}$ \\
\hline
\end{tabular}

In Table 1, even columns present estimations containing only significant coefficients. The prior vote $\left(\mathrm{V}_{\mathrm{it}-6}\right)$, the municipality's own local income tax rate $\left(\operatorname{LITR}_{\mathrm{it}-1}\right)$, the average local income tax rate in the neighbouring municipalities $\left(\mathrm{NLITR}_{\mathrm{it}-1}\right)$ and the average per capita expenditure in the neighbouring municipalities $\left(\mathrm{NEXP}_{\mathrm{it}-1}\right)$ have a significant impact on the vote percentage of government parties. Local tax policy thus has an impact on election results. Our regression results show that the government's local income tax rate negatively influences the vote percentage. High local income tax rates are thus electorally costly. The average local income tax rate of the neighbouring municipalities affects the vote percentage positively, so voters use the tax policies of surrounding municipalities as a yardstick. As in Vermeir \& Heyndels (2006), per capita expenditures in neighbouring municipalities have a negative effect on the vote

18 Insignificant party dummies are left out. The Wald test is performed for the remaining party dummies. 
percentage, while there is no significant impact of the expenditure level in the municipality itself.

The results of the regressions with and without party dummies are highly comparable. Party effects are not jointly significant in the overall regression, while they are in the most efficient regression -this is a regression with only significant coefficients as shown in column 4 . This effect is largely due to the impact of the Liberal party, which sweeps the impact of fragmentation aside. ${ }^{19}$

Finally we find that voters do not seem to hold local governments responsible for macroeconomic policy. Indeed macro-economic policy is a federal responsibility and therefore we fail to find a significant impact of the unemployment rate and of the income level on the vote percentage for local Flemish governments.

The results above (in column 4) are highly comparable to those of Vermeir \& Heyndels (2006). ${ }^{20}$ All presented significant variables of our estimation are also retrieved in Vermeir \& Heyndels (2006) with comparable coefficients. We are not able to find an effect of government fragmentation, nor of per capita income on the vote share for government parties when using one-year lagged variables. However, we have succeeded in explaining a proportion of the total variation in vote share $\left(\mathrm{R}^{2}\right)$ that is somewhat higher than that of Vermeir \& Heyndels (2006). In general, we may conclude that estimating vote results in the pre-election years differs little from estimating vote results in the election year. This is not surprising as we have used the same estimation method, the same dependent variable and explanatory variables, the only difference being the one-year lag. Most of these lagged variables evolve only gradually, year by year.

The next step is to calculate the forecasted values of the vote percentage resulting from the reestimation of Vermeir \& Heyndels' (2006) vote-function, using one year lagged dependent variables. ${ }^{21}$ In Table A2 on p. 28 in appendix we present some statistics on both the forecasted values resulting from the preceding analysis $\left(\mathrm{V}^{*}{ }_{i t}\right)^{22}$ and the outcome of elections $\left(\mathrm{V}_{\mathrm{it}}\right)$. Mean, median and maximum values are highly comparable. The minimum value is higher when the vote percentage is forecasted, suggesting optimism by incumbents expecting a low vote percentage. The correlation between the two values is 0.65 . Whether or not these forecasted values explain strategic debt policy is estimated in the following section.

19 The dummy for the presence of the Liberal party in the governments has coefficient 2.466 , t-value 3.31 and probability $<0.01$. Other party dummies are insignificant.

20 We compare to Vermeir \& Heyndels' (2006) 2SLS results as presented in column (4) of (their) Table 5 (on p. 2294).

21 We take the forecasted values from the specification in column (4) of Table 1, as it has the highest $\mathrm{R}^{2}$.

22 To indicate that we use forecasted values, we put an asterisk $\left(^{*}\right)$ to $\mathrm{V}_{\text {it }}$. 


\subsection{Strategic use of debt}

In this section we test for the existence of strategic use of debt in Flemish municipalities on a dataset covering four election periods (1982, 1988, 1994 and 2000). Due to the use of two lags of the dependent variable as instruments ${ }^{23}$, the main results are based on the 1994 and 2000 data. This covers 272 municipalities. Though there are 308 municipalities, data availability precludes the use of more than these 272 .

The model in this section is built on that of Pettersson-Lidbom (2001). This model has not only been tested -and confirmed the strategic debt hypothesis- at the local level before; it also permits us to distinguish between the PS and the AT models. The Pettersson-Lidbom (2001) model explains debt policy in election years. The theory of the strategic use of debt predicts governments not expecting to be re-elected in the next election to issue debt. If so, debt policy in election years should be a function of the governments' expectation of electoral defeat. To empirically test this hypothesis, we run -like Pettersson-Lidbom (2001)- regression (II.), which explains debt policy in election years:

(II.) $\operatorname{DEBT}_{\mathrm{it}}=\beta_{1}+\beta_{2} \mathrm{PED}_{\mathrm{it}}+\mathrm{X}_{\mathrm{it}}+\mathrm{u}_{\mathrm{it}}$; where $: \mathrm{i}=1, \ldots, \mathrm{N} ; \mathrm{t}=$ election years

The dependent variable $\mathrm{DEBT}_{\text {it }}$ measures the amount of debt per capita (in €1000).

Although we follow Pettersson-Lidbom's (2001) model, we are -as mentioned in the previous section- not convinced that his approach to estimating the probability of electoral defeat cannot be improved. Therefore we build on the estimation of the vote percentage $\left(\mathrm{V}^{*}{ }_{\mathrm{it}}\right)$ from the previous section to take into account the government's prospects of electoral defeat.

We transform $\mathrm{V}^{*}{ }_{i t}$ to a dummy variable $\left(\mathrm{PED}_{\mathrm{it}}\right)$, as we do not expect the level of debt to depend on the expected vote percentage, but only on the expectation of government continuation. Norpoth \& Gschwend (2003) find that governing coalitions whose parties obtain a majority in an election usually remain in office. Therefore we assume that a government that again gets a majority of the votes stays in office, while those who fail in that objective are replaced by a new government. Dummy variable PED $_{\text {it }}$ takes this assumption into account and takes value 1 if the government does not expect to achieve a majority again at the next elections, and thus will be voted out of office, and 0 if it expects to get its mandate renewed. This dummy variable equals 1 if the forecasted vote expectations are below majority $\left(\mathrm{V}^{*}{ }_{\mathrm{it}}<50 \%\right)$ and 0 otherwise.

23 We introduce two lags of the dependent variable as instruments in our GMM-SYS approach. See the next section for more details on the methodology. 
Like Pettersson-Lidbom (2001), we try to discriminate between the PS and AT models. According to the AT model we may expect governments with expectations of defeat to issue debt irrespective of their political ideologies. Conversely, the PS model predicts that only rightist governments issue debt when they expect to be replaced, while leftist governments are expected to do the opposite. The introduction of an interaction variable with product terms $\mathrm{PED}_{\text {it }}$ on the one hand and dummy variable $\mathrm{LEFTMAJ}_{\text {it }}-\mathrm{LEFTMAJ}_{\text {it }}$ equals 1 if leftist parties have at least $50 \%$ of the seats in the College and 0 otherwise ${ }^{24}-$ on the other hand permits to distinguish between the two models. Therefore we extend equation (II.) to :

$$
\begin{aligned}
& \text { (III.) } \operatorname{DEBT}_{\mathrm{it}}=\beta_{1}+\beta_{2} \text { PED }_{\mathrm{it}}+\beta_{3} \text { LEFTMAJ }_{\mathrm{it}} * \mathrm{PED}_{\mathrm{it}}+\beta_{4} \mathrm{LEFTMAJ}_{\mathrm{it}}+\mathrm{X}_{\mathrm{it}}+\mathrm{u}_{\mathrm{it}} \\
& \text { where }: \mathrm{i}=1, \ldots, \mathrm{N} ; \mathrm{t}=\text { election years }
\end{aligned}
$$

If our analysis should present evidence of the strategic use of debt, then in estimation (III.) $\beta_{2}$ will be significantly positive. Whether this is according to the AT or to the PS model depends on the interaction variable. If this remains insignificant, there is support for the AT model, as governments -irrespective of their political ideologies- expecting an electoral defeat increase debt. Should $\beta_{3}$ be significantly negative and should $\left(\beta_{2}+\beta_{3}\right)$ be negative, there is evidence for the PS model, in which leftist governments anticipating an electoral defeat decrease debt, while other governments with the same prospects increase debt.

Variable $\mathrm{X}_{\mathrm{it}}$ in equation (III.) stands for variables affecting debt policy. Although we expect strategic motivations for the level of debt, other determinants may also explain also this level. For this reason we add economic and political control variables.

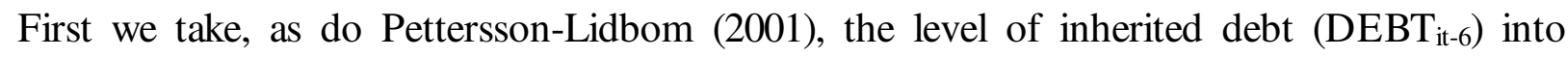
account. The level of inherited debt may have constrained the government from its preferred debt policy during the past term of office.

The impact of the inhabitants' net taxable income per capita $\left(\mathrm{NTI}_{\mathrm{it}}\right)$ on the level of debt can go both ways (Ashworth et al., 2005). On the one hand $\mathrm{NTI}_{\text {it }}$ is an indication of the fiscal capacity of the municipality -as much of the local revenue comes from local income tax- and thus may reduce the need for loan financing. On the other hand, $\mathrm{NTI}_{\mathrm{it}}$ indicates the demand for public goods and may increase this need for debt financing.

24 For the definition of our dummy variable LEFTMAJ $\mathrm{it}_{\mathrm{it}}$ we take into account the number of seats of the Socialists and of the Ecologists. In Flemish municipalities Deschouwer (1996) \& Rihoux (2001) position the Christian Democrats, the Nationalists and local parties at the centre. The Ecologists and the Socialists are at the left of the centre, while the Liberals are at the right of the centre. The anti-immigrant party Vlaams Blok (Vlaams Belang) is at the extreme right of the spectrum. Thus in our analysis, we distinguish between leftist governments $\left(\mathrm{LEFTMAJ}_{\mathrm{it}}=1\right)$ and governments on the centre or on the right of the centre $\left(\operatorname{LEFTMAJ}_{\mathrm{it}}=0\right)$. 
The proportion of young inhabitants $\left(\mathrm{YOUNG}_{\mathrm{it}}\right)$ and the proportion of elderly inhabitants $\left(\mathrm{OLD}_{\mathrm{it}}\right)$ also take into account the demand for public expenditures. ${ }^{25}$ Each time positive values are expected because higher levels of young and elderly mean a higher demand for heavy capital expenditures such as schools and care of the elderly, leading to higher levels of public debt (Bahl \& Duncombe, 1993). The same could be said for the size of the municipal population $\left(\mathrm{POP}_{\mathrm{it}}\right)$. Due to their centrality functions larger municipalities are likely to have higher demands for public goods. ${ }^{26} \mathrm{On}$ the other hand, larger municipalities may benefit from economies of scale, leading to a negative coefficient for this variable. Taking both effects together, the sign of POP $_{\text {it }}$ is a priori uncertain (Ashworth et al., 2005). Population density (DENS $\mathrm{S}_{\mathrm{it}}$ ) captures the possibility of congestion effects (Pettersson-Lidbom, 2001).

Political variables have received attention as determinants of debt policy before (see e.g. Alesina \& Perotti, 1994; Gärtner, 2000; Ashworth et al., 2005). In our regression, ideological differences are taken into account by the introduction of dummy LEFTMAJ $\mathrm{J}_{\mathrm{it}}$. We expect a positive value here, as in public finance literature it is widely accepted (see Hibbs, 1977) that leftist governments have higher spending leading to higher levels of debt. Higher spending may also be expected for fragmented governments. The Weak Government Hypothesis (Roubini \& Sachs, 1989a, 1989b) attributes higher public spending to more fragmented (or divided) governments because several conflicting political objectives have to be accommodated. Again we may assume that this may lead to higher levels of debt. However, this expectation may not be linear. We refer to Ashworth et al. (2005 \& 2006), Geys (2007) and Goeminne et al. (2008), who have previously found a non-linear effect of government fragmentation on Flemish local governments' fiscal decision-making. Ashworth et al. (2005) find that in Flemish municipalities debt reaches a maximum for coalitions of two parties and that more fragmented governments outperform such two-party governments. Therefore we introduce dummy variables TWOPAR

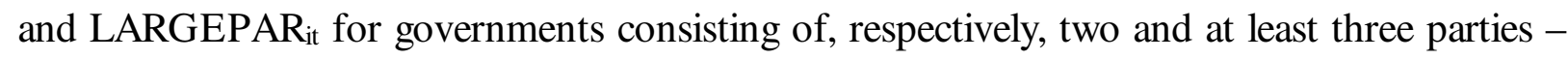
with single party governments as the remaining category- instead of introducing a single variable for the number of government parties. Finally we introduce year-dummies to capture year effects.

Replacing $\mathrm{X}_{\mathrm{it}}$ in equation (III.) with these control variables, we estimate the following equation:

YOUNG and OLD are calculated as the percentage of inhabitants that are, respectively, below 20 and over 64.

26 Larger cities have some additional "functions" compared to their neighbouring rural municipalities. For example, they serve as centres of recreation and leisure-time activities for the suburban population. They are also confronted with a flow of workers commuting between home(city) and work, as with a flow of people making use of the city as a shopping and service centre (Hansen, 1984). The use of these centre-city facilities by non-residents is likely to increase the centre cities' level of expenditures per capita. 


$$
\begin{aligned}
& \text { DEBT }_{\mathrm{it}}= \beta_{1}+\beta_{2} \text { PED }_{\mathrm{it}}+\beta_{3} \text { LEFTMAJ }_{\mathrm{it}} * \text { PED }_{\mathrm{it}}+\beta_{4} \text { LEFTMAJ }_{\mathrm{it}}+\beta_{5} \text { DEBT }_{\mathrm{it}-6}+\beta_{6} \\
& \mathrm{NTI}_{\mathrm{it}}+\beta_{7} \text { YOUNG }_{\mathrm{it}}+\beta_{8} \text { OLD }_{\mathrm{it}}+\beta_{9} \text { POP }_{\mathrm{it}}+\beta_{10} \text { DENS }_{\mathrm{it}}+\beta_{11} \text { TWOPAR }_{\mathrm{it}}+ \\
& \beta_{12} \text { LARGEPAR }_{\mathrm{it}}+\text { year dummies } \\
& \mathrm{t}
\end{aligned}
$$

where $: \mathrm{i}=1, \ldots, \mathrm{N} ; \mathrm{t}=$ election years

It is well known by now that the standard approaches to panel data analysis are inappropriate in a dynamic setting. Both fixed and random effects estimators lead to biased and inconsistent estimation results in the presence of a lagged dependent variable (Baltagi, 1995). To remove this bias, it is necessary to provide a valid set of instruments for this lagged dependent variable. Arellano \& Bond (1991) offer a solution to this problem by treating the model as a system of equations (viz. one for each time period) and developing a Generalized Method of Moments estimator that exploits the moment conditions for the equations in first differences. Specifically, the estimator is based on taking first differences of the model (to remove municipality-specific effects) and then instrumenting the lagged dependent variable in first differences with suitable lags of its own levels. In our analysis we include two lags of the dependent variable as instruments. The estimator developed by Arellano \& Bond (1991) is generally called difference GMM (or GMM-DIF). It is ideal for short time series (such as ours).

However, an important obstruction to using GMM-DIF is that the lagged values of the dependent variable may be only weak instruments in the differenced regression. This could lead to severe finite-sample bias, especially when the series is very persistent (see Blundell \& Bond, 1998). Given this, we employ system GMM estimation (GMM-SYS; Arellano \& Bover, 1995; Blundell \& Bond, 1998). This method combines the moment conditions for the equations in first differences exploited in the GMM-DIF estimator with additional moment conditions for the equations in levels. The introduction of these additional moments increases the efficiency of the estimation. Note also that we use the two-step rather than the one-step variant of GMMSYS, as the two-step variant is asymptotically more efficient. ${ }^{27}$

To assess the empirical results of our model, we apply two specification tests. First we run the Sargan test for over-identifying restrictions to verify the overall validity of the instruments. The presented Sargan statistics at the bottom of Table 2 do not permit a rejection of the null hypothesis that the instruments are uncorrelated to some set of residuals. The instruments thus pass the test. Second, one should be aware that GMM-SYS requires no second order residual autocorrelation. Therefore we adopt the Arellano (1987) approach of computing White coefficient covariance estimates which are robust to residual correlation.

27 The two-step procedure controls for the correlation of errors overtime, for heteroscedasticity across municipalities, simultaneity, and measurement errors due to the utilization of orthogonal conditions on the variance-covariance matrix (Blundell \& Bond, 1998). 
Before estimating our model, we test for the existence of multicollinearity in our dataset. Therefore we run a correlation analysis. The correlation matrix indicated that the pair wise correlation coefficients of $\mathrm{POP}_{\text {it }}$ with $\mathrm{DEBT}_{\text {it }-6}$ are over the suggested threshold of $\mathrm{r}>0.80$ (see Gujarati, 2003; 359). Therefore we shift POP it from the model.

Table 2 presents results of the two-step system GMM. Column (1) presents results including all variables. More efficient regressions in which insignificant variables are omitted are in column (2).

Table 2 Estimation results of the debt function (estimation (IV.) on p. 18), using two-step system GMM

\begin{tabular}{|c|c|c|}
\hline Dependent variable : Debt ${ }_{\text {it }}$ & (1) & (2) \\
\hline Inherited debt $\left(\right.$ Debt $\left._{\mathrm{it}-6}\right)$ & $\begin{array}{l}-0.193 \text { *** } \\
(-3.83)\end{array}$ & $\begin{array}{l}-0.205 * * * \\
(-6.99)\end{array}$ \\
\hline Prospects of electoral defeat $\left(\mathrm{PED}_{\mathrm{it}}\right)$ & $\begin{array}{l}0.160 * \\
(1.65)\end{array}$ & $\begin{array}{l}0.145 * \\
(1.93)\end{array}$ \\
\hline PED $_{\text {it }} *$ LEFTMAJ $_{\text {it }}$ & $\begin{array}{l}-0.313 * * \\
(-2.20)\end{array}$ & $\begin{array}{l}-0.292 * * \\
(-2.16)\end{array}$ \\
\hline Leftist majority (LEFTMAJ ${ }_{\text {it }}$ ) & $\begin{array}{l}0.398 \text { ** } \\
(2.21)\end{array}$ & $\begin{array}{l}0.316 * \\
(1.94)\end{array}$ \\
\hline Net Taxable Income $\left(\mathrm{NTI}_{\mathrm{it}}\right)$ & $\begin{array}{r}-0.001 \\
(0.01)\end{array}$ & - \\
\hline Proportion of young $\left(\mathrm{YOUNG}_{\mathrm{it}}\right)$ & $\begin{array}{r}1.669 \\
(0.45)\end{array}$ & - \\
\hline Proportion of elderly $\left(\mathrm{OLD}_{\mathrm{it}}\right)$ & $\begin{array}{l}4.942 \\
(0.84)\end{array}$ & - \\
\hline Population density $\left(\mathrm{DENS}_{\mathrm{it}}\right)$ & $\begin{array}{l}0.004 * \\
(1.65)\end{array}$ & - \\
\hline Two-party government $\left(\mathrm{TWOPAR}_{\text {it }}\right)$ & $\begin{array}{l}0.040 \\
(0.29)\end{array}$ & - \\
\hline Large-party government $\left(\right.$ LARGEPAR $\left._{\mathrm{it}}\right)$ & $\begin{array}{l}0.074 \\
(0.69)\end{array}$ & - \\
\hline Time dummy variable (1994) & $\begin{array}{l}-0.240 \text { *** } \\
(-2.78)\end{array}$ & $\begin{array}{l}-0.334 \text { *** } \\
(-9.60)\end{array}$ \\
\hline Time dummy variable (2000) & $\begin{array}{l}-0.1 .81 * * \\
(-2.34)\end{array}$ & $\begin{array}{l}-0.264 * * * \\
(-8.41)\end{array}$ \\
\hline Sargan & $\begin{array}{r}6.399 \\
(p=0.17)\end{array}$ & $\begin{array}{r}13.080 \\
(\mathrm{p}=0.22)\end{array}$ \\
\hline
\end{tabular}

Focusing on the strategic debt hypotheses, we find support for the strategic use of debt in Flemish municipalities. The most efficient estimation in column (2) shows that governments that do not expect re-election have a significantly different level of debt in election years, as $\mathrm{PED}_{\mathrm{it}}$ has a significant (and positive) coefficient. Whether this finding of higher debt in such governments can be generalized for all governments independent of their ideological orientation depends on the interaction variable $\left(\mathrm{PED}_{\mathrm{it}}\right.$ * $\mathrm{LEFTMAJ}_{\mathrm{it}}$ ), which allows us to distinguish between the PS and AT models. It is clear from Table 2 that the coefficient of the interaction term is negative and highly significant and thus strongly suggests that left-wing governments with bad re-election prospects have different slope coefficients. Moreover, the slope coefficient for a left-wing government $\left(\beta_{2}+\beta_{3}\right)$ is negative. Our results thus meet both conditions for providing evidence for the PS model. 
Leftist governments not expecting to get into office again reduce debt by $€ 147$ per capita, while other governments with the same perspective increase debt by $€ 145 .^{28}$

These findings thus show that governments act strategically when they expect not to get into office again. Moreover, the nature of their reaction is different according to their ideological position. Leftist governments in this position reduce debt, while other governments in the same position issue higher debts. This is in line with the theoretical expectations of the PS model. In accordance with Pettersson-Lidbom (2001), we thus find evidence of the use of strategic debt in line with the PS model at the local level.

Turning to the control variables, we find that the inherited debt presents a significant negative coefficient. In line with the theoretical expectations, we find that leftist governments, irrespective of their prospects of electoral defeat, have higher debts. The simple main effect of LEFTMAJ $_{\text {it }}$ presents a statistically significant positive coefficient. The debt-level of leftist governments is per capita on average $€ 316$ in excess of that of other governments. Finally, there is no evidence that other variables representing the needs for public expenditure $\left(O L D_{i t}\right.$, YOUNG $_{\text {it }}$, and DENS $\mathrm{Dit}_{\mathrm{i}}$ ), or fragmentation variables significantly determine the level of debt in election years.

\subsection{Extension}

The findings in the previous section confirm the existence of strategic use of debt corresponding to the PS model in Flemish municipalities. However, these findings can be nuanced. In this section we perform first an additional test concerning the role of government fragmentation and second we discuss a number of robustness tests relative to our crucial variable PED it. $_{\text {. }}$

As to government fragmentation, we introduced in estimation (IV.) some fragmentation variables. These variables control for different levels of debt according to the level of fragmentation. As can be seen in Table 2, there is no significant impact of government fragmentation on the level of debt in election years. Still, this does not necessarily mean that fragmentation has no impact on strategic debt behaviour. It can play a role in strategic debt behavior too by means of a different reaction of a single party government and of a coalition government confronted with the same probability of electoral defeat. ${ }^{29}$ Ashworth et al. (2006) state that parties in a coalition are on average less certain of future power than parties not sharing power. Indeed, coalition parties not only have to 'win' the elections; they also have to

\footnotetext{
28 The dependent variable is expressed in $€ 1000$ per capita. $€ 145$ is the value of coefficient $\beta_{2}$, while $€ 147$ is the sum of $\beta_{2}+\beta_{3}$.

29 We thank Bruno Heyndels for this suggestion.
} 
survive the ensuing coalition negotiations. Hence, their shorter time horizon may lead coalition governments to be more sensitive to the strategic use of debt. We thus expect fragmented governments to more strongly (and consciously) engage in debt creation in election years. To test this hypothesis, we rerun our regression separately for single party governments and for coalition governments. Results are presented in Table 3. For single party governments see columns (1) and (2), for the coalition governments columns (3) and (4).

Table 3 Estimation results of the debt function (estimation (IV.) on p. 18) for single party governments and for coalition governments, using two-step system GMM

\begin{tabular}{|c|c|c|c|c|}
\hline \multirow{2}{*}{ Dependent variable : Debt $_{i t}$} & \multicolumn{2}{|c|}{ Single party governments $(\mathrm{N}=215)$} & \multicolumn{2}{|c|}{ Coalition governments $(\mathrm{N}=241)$} \\
\hline & (1) & (2) & (3) & (4) \\
\hline Inherited debt (Debt $\left.\mathrm{Dit}^{-6}\right)$ & $\begin{array}{l}1.248 * * * \\
(4.80)\end{array}$ & $\begin{array}{l}1.129 * * * \\
(5.12)\end{array}$ & $\begin{array}{l}-0.334 \text { **** } \\
(-8.48)\end{array}$ & $\begin{array}{l}-0.372 \text { *** } \\
(-11.72)\end{array}$ \\
\hline Probability of electoral defeat $\left(\mathrm{PED}_{\text {it }}\right)$ & $\begin{array}{l}0.039 \\
(0.63)\end{array}$ & $\begin{array}{l}0.058 \\
(1.05)\end{array}$ & $\begin{array}{l}0.138 \\
(1.03)\end{array}$ & $\begin{array}{l}0.222 \text { ** } \\
(2.06)\end{array}$ \\
\hline $\mathrm{PED}_{\mathrm{it}} * \mathrm{LEFTMAJ}_{\mathrm{it}}$ & $\begin{array}{l}-0.050 \\
(-0.42)\end{array}$ & $\begin{array}{r}-0.060 \\
(-0.65)\end{array}$ & $\begin{array}{l}-0.335 * * \\
(-2.17)\end{array}$ & $\begin{array}{l}-0.323 * * \\
(-2.07)\end{array}$ \\
\hline Leftist majority (LEFTMAJ ${ }_{\text {it }}$ ) & $\begin{array}{l}0.139 \\
(1.01)\end{array}$ & $\begin{array}{l}0.154 \\
(1.51)\end{array}$ & $\begin{array}{l}0.396 \text { ** } \\
(2.16)\end{array}$ & $\begin{array}{l}0.344 * \\
(1.86)\end{array}$ \\
\hline Net Taxable Income $\left(\mathrm{NTI}_{\mathrm{it}}\right)$ & $\begin{array}{l}0.003 \\
(0.15)\end{array}$ & - & $\begin{array}{l}-0.033 \\
(-0.59)\end{array}$ & - \\
\hline Proportion of young $\left(\mathrm{YOUNG}_{\mathrm{it}}\right)$ & $\begin{array}{l}3.685 \\
(1.60)\end{array}$ & - & $\begin{array}{l}2.270 \\
(0.41)\end{array}$ & - \\
\hline Proportion of elderly $\left(O L D_{i t}\right)$ & $\begin{array}{l}2.472 \\
(0.80)\end{array}$ & - & $\begin{array}{l}-0.106 \\
(-0.01)\end{array}$ & - \\
\hline Population density $\left(\mathrm{DENS}_{\mathrm{it}}\right)$ & $\begin{array}{l}-0.001 \\
(-0.48)\end{array}$ & - & $\begin{array}{r}0.004 \\
(1.38)\end{array}$ & - \\
\hline Time dummy variable (1994) & $\begin{array}{l}-0.089 \\
(-1.65)\end{array}$ & $\begin{array}{l}-0.086 \text { ** } \\
(-2.51)\end{array}$ & $\begin{array}{l}-0.461 \text { **** } \\
(-2.87)\end{array}$ & $\begin{array}{l}-0.396 \text { **** } \\
(-7.39)\end{array}$ \\
\hline Period dummy variable (2000) & $\begin{array}{r}0.079 \\
(1.53)\end{array}$ & (20) & $\begin{array}{l}-0.425 \\
(-2.95)\end{array}$ & $\begin{array}{l}-0.375 * * * \\
(-7.59)\end{array}$ \\
\hline Sargan & $\begin{array}{r}4.937 \\
(\mathrm{p}=0.18)\end{array}$ & $\begin{array}{r}7.064 \\
(p=0.53)\end{array}$ & $\begin{array}{r}5.043 \\
(p=0.28)\end{array}$ & $\begin{array}{r}10.091 \\
(p=0.26)\end{array}$ \\
\hline
\end{tabular}

Note : t-values between brackets (except for the Sargan tests where $\mathrm{p}$-values are presented); ${ }^{*}$ significant at $10 \%$, ** significant at $5 \%$ and $* * *$ significant at $1 \%$.

The results confirm the possibility discussed above. When reviewing the results for single party governments and for coalition governments, we can confirm the existence of strategic use of debt by coalition governments, but not by single party governments. The presented coefficients of the crucial strategic use of debt variables are insignificant for single party governments (see column 2) ${ }^{30}$, while they meet the conditions to present evidence of strategic use of debt in line with the PS model for coalition governments. Comparing the findings for coalition governments in column (4) of Table 3 with the overall results from column (4) of Table 2, (absolute values of the) coefficients are increased, suggesting stronger effects of all variables on the level of debt. We can thus conclude that strategic debt behaviour is a phenomenon that can be observed especially in fragmented government scenarios. This may be due to the fact that as well as the electoral results, the ensuing coalition negotiations play a role in whether or not the government can continue with the same coalition partners as in the previous term.

30 Unlike previous presentations of regression results we present here insignificant coefficients. 
Second, we performed robustness tests. The novelty of this paper has been that -unlike most previous literature on strategic debt models- we do not not rely solely on historical political stability or on ex-post information to estimate the probability of electoral defeat. Nevertheless, we wonder what the results would be if we do rely only on such measurements. Below we reestimate equation (IV.) replacing “our” PED ${ }_{\text {it }}$ by two alternatives. ${ }^{31}$ First we take into account ex post electoral results as a proxy for the probability of electoral defeat. As a second alternative we introduce the government's seats margin. Results are in Table 4.

Table 4 Estimation results of the debt function (estimation (IV.) on p. 18) with alternative proxies of the probability of electoral defeat, using two-step system GMM

\begin{tabular}{|c|c|c|c|c|}
\hline \multirow{2}{*}{ Dependent variable : Debt $_{\text {it }}$} & \multicolumn{2}{|c|}{ Ex-post observation of electoral defeat } & \multicolumn{2}{|c|}{ Seats margin } \\
\hline & $(1)$ & (2) & (3) & (4) \\
\hline Inherited debt $\left(\mathrm{Debt}_{\mathrm{it}-6}\right)$ & 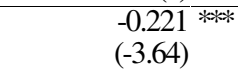 & $\begin{array}{l}-0.183 * * * * \\
(-5.69)\end{array}$ & $\begin{array}{l}-0.194 * * * \\
(-3.57)\end{array}$ & $\begin{array}{l}-0.191 \text { *** } \\
(-6.57)\end{array}$ \\
\hline Ex-post electoral defeat $\left(\mathrm{EED}_{\text {it }}\right)$ & $\begin{array}{l}0.511 \\
(1.28)\end{array}$ & $\begin{array}{l}0.261 \text { ** } \\
(2.06)\end{array}$ & (1) & (1) \\
\hline EED $_{\text {it }} *$ LEFTMAJ $_{\text {it }}$ & $\begin{array}{l}-0.581 \text { ** } \\
(-2.33)\end{array}$ & $\begin{array}{l}-0.436 * \\
(-1.83)\end{array}$ & - & - \\
\hline Seat margin $\left(\mathrm{SEATMAR}_{\mathrm{it}}\right)$ & 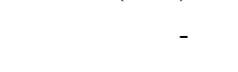 & - & $\begin{array}{l}-0.791 * * * \\
(-2.69)\end{array}$ & $\begin{array}{l}-0.757 \text { *** } \\
(-2.72)\end{array}$ \\
\hline SEATMAR $_{\text {it }} *$ LEFTMAJ $_{\text {it }}$ & - & - & $\begin{array}{l}0.286 \\
(0.25)\end{array}$ & - \\
\hline Leftist majority (LEFTMAJit) & $\begin{array}{l}0.460 \text { ** } \\
(2.17)\end{array}$ & $\begin{array}{l}0.414 \text { ** } \\
(2.19)\end{array}$ & $\begin{array}{l}0.280 \\
(1.45)\end{array}$ & $\begin{array}{l}0.311 \text { ** } \\
(2.11)\end{array}$ \\
\hline Net Taxable Income $\left(\mathrm{NTI}_{\mathrm{it}}\right)$ & $\begin{array}{l}-0.020 \\
(-0.47)\end{array}$ & - & $\begin{array}{l}-0.004 \\
(-0.14)\end{array}$ & - \\
\hline Proportion of young $\left(\mathrm{YOUNG}_{\mathrm{it}}\right)$ & $\begin{array}{l}-0.370 \\
(-0.08)\end{array}$ & - & $\begin{array}{l}0.982 \\
(0.25)\end{array}$ & - \\
\hline Proportion of elderly $\left(O L D_{i t}\right)$ & $\begin{array}{l}0.629 \\
(0.09)\end{array}$ & - & $\begin{array}{l}4.367 \\
(0.62)\end{array}$ & - \\
\hline Population density $\left(\mathrm{DENS}_{\mathrm{it}}\right)$ & $\begin{array}{l}0.003 \\
(1.23)\end{array}$ & - & $\begin{array}{l}0.005 * \\
(1.87)\end{array}$ & $\begin{array}{l}0.003 * \\
(1.76)\end{array}$ \\
\hline Two-party government (TWOPAR $\left.{ }_{i t}\right)$ & $\begin{array}{l}0.206 \\
(0.79)\end{array}$ & - & $\begin{array}{l}0.003 \\
(0.02)\end{array}$ & - \\
\hline Large-party government (LARGEPAR ${ }_{\mathrm{it}}$ ) & $\begin{array}{l}0.276 \\
(0.95)\end{array}$ & - & $\begin{array}{l}0.029 \\
(0.31)\end{array}$ & - \\
\hline Time dummy variable (1994) & $\begin{array}{l}-0.570 \text { ** } \\
(-1.99)\end{array}$ & $\begin{array}{l}-0.550 \text { **** } \\
(-10.29)\end{array}$ & $\begin{array}{l}-0.423 \\
(-1.68)\end{array}$ & $\begin{array}{l}-0.526 \text { **** } \\
(-8.14)\end{array}$ \\
\hline Time dummy variable (2000) & $\begin{array}{l}-0.327 * \\
(-1.93)\end{array}$ & $\begin{array}{l}-0.331 \\
(-8.22)\end{array}$ & $\begin{array}{l}-0.240 \\
(-1.52)\end{array}$ & $\begin{array}{l}-0.305 \text { *** } \\
(-6.83)\end{array}$ \\
\hline Sargan & $\begin{array}{r}6.927 \\
(p=0.13)\end{array}$ & $\begin{array}{r}14.334 \\
(p=0.16)\end{array}$ & $\begin{array}{r}6.501 \\
(p=0.17)\end{array}$ & $\begin{array}{r}7.048 \\
(p=0.80)\end{array}$ \\
\hline
\end{tabular}

First, we introduce ex-post vote share for the incumbents as a proxy for the probability of electoral defeat. We thus exchange the prospects of electoral defeat $\left(\mathrm{PED}_{\mathrm{it}}\right)$ for the ex-post observation of electoral defeat $\left(\mathrm{EED}_{\mathrm{it}}\right)$. Again this variable is constructed as a dummy variable and takes value 1 if the government has left office and 0 otherwise. Column (1) of Table 4 presents results including all variables, while the more efficient regression in which insignificant

31 Most of the estimates in literature on strategic debt rely on data that goes back more than one term. E.g Grilli et al. (1991), Pettersson-Lidbom (2001), Franzese (2001) and Crain \& Tollison (1993) take into account the frequency of government changes in the past. Franzese (2001) uses the actual duration of the incumbent's mandate. The setting of Flemish municipalities do not lend itself to suchlike variables that go back more than one term. First, there was the large-scale municipal amalgamation in 1976. This hinders the calculation of a frequency of governments changes with statisfactory variation. Second, local parties in Flemish municipalities frequently change their names or merge (see also footnote 11). Such characteristics make it difficult to calculate the duration of the incumbents' mandate as they may stay in office - and carry on their policy- while they changed the name of the party. 
variables are omitted is in column (2). The results are qualitatively similar to those using the expectations of electoral defeat as shown in Table 2 on p. 19. When rerunning the analysis using ex post results, we thus find almost the same results. Again there is evidence of strategic debt in line with the PS model. This equality could indicate that a vote function is a reliable instrument with which to estimate actual vote results and is thus a good proxy for the probability of electoral defeat. Theoretically one could thus use ex post electoral information when searching for evidence of the strategic use of debt. But incumbents still have to estimate their survival probability before elections. Our results thus show that in practice the determinants of the vote function permit governments to estimate their probability of electoral defeat.

Second, Ashworth et al. $(2005,403)$ consider that "governments with larger electoral margins may find it easier to remain in power after the next election". This would lower the incentive to strategically use debt. Therefore we introduce SEATMAR, which takes into account the seats margin of the government. We compute the seats margin as the difference between the percentage of the seats of the government parties in the Council and 50\%. The expectation is that higher margins lower the incentive to strategically use debt, so we expect the seats margin to negatively affect the level of debt. In contrast to Ashworth et al. (2005) -who fail to find evidence of strategic debt behaviour- columns (3) and (4) of Table 4 show that SEATMAR has a significant negative coefficient. This means that governments with lower seats margins have higher debts and we may conclude that these findings support the strategic use of debt in Flemish municipalities conform the AT model.32 Contrary to our previous results, the interaction variable remains insignificant. We are thus unable to confirm the existence of strategic use of debt in line with the PS model when introducing the seats margin as a proxy for the probability of electoral defeat.

\section{Conclusion}

This paper discusses the literature on strategic use of debt models and empirically tests the seminal models of Persson \& Svensson (1989) and Alesina \& Tabellini (1990) on a dataset of Flemish municipalities. The literature shows that the evidence is mixed and we suggest that the lack of an undisputed measure to estimate the probability of electoral defeat obstructs the formulation of a general consensus on this matter. Most of these measures are based on historical political stability information, which ignores the fact that incumbents have to try to estimate what voters have in mind in the voting booth when estimating the government's

32 Our results differ from Ashworth et al. (2005) who explain debt on a dataset containing all years of the period 1977-2000. These different findings may be explained by the fact that the objective of their analysis and their dataset is different from ours -they do not focus on election years only. To stress the role of strategic debt in election years, they should have entered the seats margin in interaction with a dummy for election years. 
probability of electoral defeat. As Baleiras $(1997,202)$ explicitly states "this probability depends on the electorate's assessment of the incumbent's performance while in office". They thus consider not only historical, but also tax, economic and political variables. Therefore we introduce vote functions to estimate the prospects of electoral defeat. For the purpose of this paper the vote function of Vermeir \& Heyndels (2006) is slightly adapted in an attempt to construct a good proxy for the prospects of electoral defeat. Our main results show that debt increases in election years when the government expects an electoral defeat and thus present evidence of strategic use of debt in Flemish municipalities. Moreover we are able to differentiate according to the governments ideological preferences. Like Petterson-Lidbom (2001), we find evidence of the strategic use of debt in line with the Persson \& Svensson (1989) model at the local level. However, our analyses show that strategic debt behaviour is more to be expected in the case of leftist coalition governments. When running separate analyses for single party governments and for coalition governments, we find only significant strategic debt coefficients for the latter. This may be due to the fact that coalition governments have both to win the elections and also to survive the ensuing coalition negotiations. This increases their uncertainty of returning to office and as a consequence their motivation to strategically issue debt. To check the robustness of the general results, the strategic use of debt analysis was reran using ex post election results and the seats margin (instead of the results from the vote function) as a proxy for the probability of electoral defeat. Similar results are presented when ex post election results are introduced. This may suggest that a vote function is a reliable instrument for estimating the probability of electoral defeat. When the seats margin is used as a proxy, the presence of strategic use of debt in Flemish municipalities may be confirmed, though not in line with the PS-type but with the AT-type. 


\section{References}

Aghion, P. \& Bolton, P., 1990, Government domestic debt and the risk of default: a politicaleconomic model of the strategic role of debt. In: Dornbusch, R., Draghi, M., Public Debt Management: Theory and History. Cambridge : Cambridge Univ. Press, 315-345.

Alesina, A., Cohen, G. \& Roubini, N., 1992, Macroeconomic policies and election in OECD democracies, Economics \& Politics 4, 1-30.

Alesina, A. \& Perotti, R., 1994, The political economy of budget deficits, NBER Working Paper $\mathrm{N}^{\circ} 4637$.

Alesina, A. \& Tabellini, G., 1990, A positive theory of fiscal deficits and government debt, Review of Economic Studies 57, 403-414.

Arellano, M., 1987, Computing Robust Standard Errors for Within-groups Estimators, Oxford Bulletin of Economics and Statistics 49, 431-434.

Arellano, M. \& Bond, S., 1991, Some tests of specification for panel data: Monte Carlo evidence and an application to employment equations, Review of Economic Studies 58, 277-297.

Arellano, M. \& Bover, O., 1995, Another look at the instrumental variable estimation of errorcomponents models, Journal of Econometrics 68, 29-51.

Ashworth, J., Geys, B. \& Heyndels, B., 2005, Government weakness and local public debt development in Flemish municipalities, International Tax and Public Finance 12(4), 395-422.

Ashworth, J., Geys, B. \& Heyndels, B., 2006, Determinants of tax innovation: The case of environmental taxes in Flemish municipalities, European Joumal of Political Economy 22 (1), 223-247.

Bahl, R. W. \& Duncombe, W. D., 1993, State and Local Debt Burdens in the 1980s: A Study in Contrast, Public A dministration Review 53, 31-49.

Baltagi, B., 1995, Econometric A nalysis of Pand Data. London : John Wiley.

Barro, R., 1979, On the determination of the public debt, Journal of Political Economy 87(5), 940971.

Besley, T. \& Case, A., 1995, Incumbent behavior: Vote seeking, tax setting and yardstick competition, A merican Economic Review 85, 25-45.

Blundell, R. \& Bond, S., 1998, Initial conditions and moment restrictions in dynamic panel data models, Journal of Econometrics 87, 115-143.

Carmignani, F., 2003, Political instability, uncertainty and economics, Journal of Economic Surveys $17(1), 1-54$.

Crain, W. M. \& Tollison, R. D., 1993, Time inconsistency and fiscal policy - Empirical analysis of U.S. States, 1969-89, Journal of Public Economics 51, 153-159.

Deschouwer, K., 1996, Nationale partijen en gemeenteraadsverkiezingen, in Buelens J. \& Deschouwer, K. (eds.), De dorpsstraat is de wetstraat niet. Brussel : VUBPress, 13-25. 
Fischer, S., 1980, Dynamic inconsistency, cooperation and the benevolent dissembling government, Journal of Economic Dynamics and Control 2(1), 93-107.

Franzese, R. J., 2001, The positive political economy of public debt : an empirical examination of the OECD postwar experience, mimeo, pp. 68.

Frey, B. \& Schneider, F., 1978, A politico-economic model of the United Kingdom, The Economic Journal 88, 243-253.

Gärtner, M., 2000, Political macroeconomics : a survey of recent developments, Journal of Economic Surveys 5/ 14, 527-561.

Geys, B., 2007, Government Weakness and Local Public Debt Cycles: Evidence from Flemish Municipalities, Local Govemment Studies 33(2), 239-253.

Geys, B. \& Vermeir, J., 2008, The political cost of taxation : new evidence from German popularity ratings, Electoral Studies, accepted for publication.

Goeminne, S., Geys, B. \& Smolders, C., 2008, Political fragmentation and projected tax revenues: evidence from Flemish municipalities, International Tax and Public Finance 15(3), 297-315.

Grilli, V., Masciandaro, D \& Tabellini, G., 1991, Political and monetary institutions and public financial policies in the industrial countries, Economic Policy 6(2), 341-392.

Gujarati, D. N., 2003, Basic Econometrics. New York : McGraw-Hill.

Hansen, T., 1984, Urban Hierarchies and Municipal Finances, European Journal of Political Research 12, 343-356.

Heath, A., McLean, I., Taylor, B. \& Curtice, J., 1999, Between first and second order : a comparison of voting behavior in European and local elections in Britain, European Journal of Political Research 35, 389-414.

Hibbs, D., 1977, Political Parties and Macro-Economic Policy, A merican Political Saience Review 71, 1467-1487.

Jérôme, B. \& Lewis-Beck, M. S., 1999, Is local politics local? French evidence, European Journal of Political Research 35, 181-197.

Kydland, F. \& Prescott, E., 1977, Rules rather than discretion : the inconsistency of optimal plans, Journal of Politcal Economy, 473-492.

Lambertini, L., 2003, Are budget deficits used strategically?, Working Papers In Economics, Boston College, $40 \mathrm{pp}$.

Lewis-Beck, M. S. \& Paldam, M., 2000, Economic voting : an introduction, Electoral Studies 191, 113-121.

Lockwood, B., Philippopoulos, A. \& Snell, A., 1996, Fiscal policy, public debt stabilisation and politics : theory and UK evidence, The Economic Journal 106, 894-911.

Martimort, D., 2001, Optimal taxation and strategic budget deficit under political regime switching, The Review Of Economic Studies Limited 68, 573-592. 
Milesi-Ferretti, G., 1995, Do good or do well? Public debt management in a two-party economy, Economics and Politics 7(1), 58-74.

Milesi-Ferretti, G. \& Spolaore, E., 1994, How cynical can an incumbent be? Strategic policy in a model of government spending, Journal of Public Economics 55(1), 121-140.

Mughan, A., 1987, General election forecasting in Britain : a comparison of three simple models, Electoral Studies 6, 195-207.

Nannestad, P. \& Paldam, M., 1994, The VP-function : a survey of the literature on vote and popularity functions after 25 years, Public Choice 79, 213-245.

Nicholson, S. P. \& Segura, G. M., 2002, Presidential approval and the mixed blessing of divided government, The Journal of Politic 64, 701-720.

Norpoth, H. \& Gschwend, T., 2003, Against all odds? The Green-Red victory, German Politics and Society 21(1), 15-34.

Paldam, M. \& Schneider, F., 1980, The macro-economic aspects of government and opposition popularity in Denmark 1957-1978, Nationalokonomisk Tidssk rift 2, 149-170.

Persson, T. \& Svensson, L. E. O., 1989, Why a stubborn conservative would run a deficit : policy with time-inconsistent preferences, The Quarterly Journal of Economics 104, 325-345.

Pettersson-Lidbom, P., 2001, An emperical investigation of the strategic use of debt, Journal of Political Economy 109(3), 570-583.

Powell, G. B. \& Whitten, G. D., 1993, A cross-national analysis of economic voting : taking account of the political context, A merican Joumal of Political Saience 37, 391-414.

Revelli, F., 2002, Local taxes, national politics and spatial interactions in English district election results, European Journal of Political Economy 18, 281-299.

Rihoux, B., 2001, Iedereen naar het politieke centrum en voorstander van de Nieuwe Politieke Cultuur : de ideologische positionering van de lokale partijafdelingen in België, Tijdschrift van Dexia Bank 216, 7-18.

Roubini, N. \& Sachs, J., 1989a, Government spending and budget deficits in the industrial countries, Economic Policy 8, 99-132.

Roubini, N. \& Sachs, J., 1989b, Political and economic determinants of budget deficits in the industrial economies, European Economic Review 33, 903-938.

Schneider, F. \& Pommerehne, W. W., 1980, Politico-economic interactions in Australia : some empirical evidence, The Economic Record 56(2), 113-131.

Solé Ollé, A., 2003, Electoral accountability and tax mimicking : the effects of electoral margins, coalition government and ideology, European Journal of Political Economy 19, 685-713.

Vermeir, J. \& Heyndels, B., 2006, Tax policy and yardstick voting in Flemish municipal elections, A pplied Economics 38, 2285-2298. 


\section{Appendices}

Table A1 Descriptive statistics of the variables in the vote function $(\mathrm{N}=688)$ and data sources

\begin{tabular}{|c|c|c|c|c|c|c|}
\hline & Mean & Median & Max & Min & Std.dev. & Source \\
\hline Dep. Var. : Vote share (in \%) government parties $\left(\mathrm{V}_{\mathrm{it}}\right)$ & 54.93 & 54.04 & 87.30 & 24.15 & 10.18 & MICE, VUB 33 \\
\hline Vote share (in $\%)$ current government parties at $\mathrm{t}-6\left(\mathrm{~V}_{\mathrm{it}-6}\right)$ & 56.24 & 55.08 & 88.29 & 37.25 & 8.32 & MICE, VUB \\
\hline Local income tax rate $\left(\mathrm{LITR}_{\mathrm{it}-1}\right)$ & 6.60 & 7.00 & 9.00 & 0.00 & 0.89 & VVSG $^{34}$ \\
\hline Local property tax rate $\left(\mathrm{LPTR}_{\mathrm{it}-1}\right)$ & 963.76 & 950.00 & 2000.00 & 170.00 & 265.42 & VVSG \\
\hline Per capita expenditures (in $1000 €)\left(\mathrm{EXP}_{\mathrm{it}-1}\right)$ & 0.47 & 0.42 & 2.32 & 0.14 & 0.19 & MICE, VUB \\
\hline 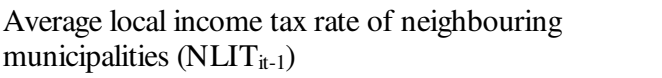 & 6.67 & 6.60 & 8.50 & 5.33 & 0.46 & $\begin{array}{l}\text { VVSG, matrix of } \\
\text { MICE, VUB }\end{array}$ \\
\hline 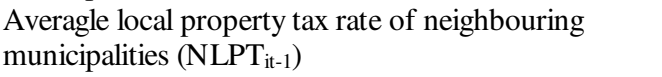 & 971.43 & 962.85 & 1650.00 & 400.00 & 199.01 & $\begin{array}{l}\text { VVSG, matrix of } \\
\text { MICE, VUB }\end{array}$ \\
\hline $\begin{array}{l}\text { Average per capita expenditures of neighbouring } \\
\text { municipalities (in } 1000 €)\left(\mathrm{NEXP}_{\mathrm{it}-1}\right)\end{array}$ & 590.66 & 584.36 & 1392.99 & 282.57 & 173.53 & $\begin{array}{l}\text { VVSG, matrix of } \\
\text { MICE, VUB }\end{array}$ \\
\hline Net taxable income (in 1000000€) $\left(\mathrm{NTI}_{\mathrm{it}-1}\right)$ & 159.21 & 106.67 & 3283.25 & 0.84 & 221.03 & FPSEconomy ${ }^{35}$ \\
\hline Unemployment rate (UNEMPL $\left.\mathrm{L}_{\mathrm{it}-1}\right)$ & 0.03 & 0.03 & 0.16 & 0.01 & 0.01 & CORE, $\mathrm{UCL}^{36}$ \\
\hline Numbers of parties in the government $\left(\mathrm{NPAR}_{\mathrm{it}-1}\right)$ & 1.63 & 2.00 & 5.00 & 1.00 & 0.68 & MICE, VUB \\
\hline
\end{tabular}

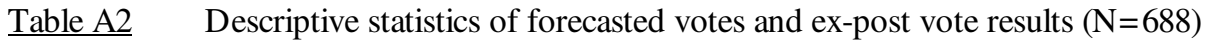

\begin{tabular}{lrr}
\hline & Forecasted votes & Ex-post votes \\
\hline Mean & 54.93 & 54.93 \\
Median & 54.20 & 54.07 \\
Maximum & 87.68 & 87.30 \\
Minimum & 32.43 & 24.15 \\
Std. Dev. & 9.67 & 10.18 \\
\hline Correlation & \multicolumn{2}{c}{0.65} \\
\hline
\end{tabular}

33 MICE (Micro-Economics for Profit and Non Profit Sector) research team of the Faculty of Economic, Social and Political Sciences, and Solvay Business School, Vrije Universiteit Brussel.

34 "Vereniging Vlaamse Steden en Gemeenten", the Association of Flemish Cities and Municipalities.

35 Belgian Federal Public Service Economy, SME, Independent Professions and Energy

36 CORE (Center for Operations Research and Econometrics), Université catholique de Louvain. 